University of Nebraska - Lincoln

DigitalCommons@University of Nebraska - Lincoln

Faculty Publications: Department of Entomology

1995

\title{
Field Evaluation of Pheromone-Baited Traps for Coniesta ignefusalis (Lepidoptera: Pyralidae) in Niger
}

Ousmane Youm

University of Nebraska-Lincoln, oyoum2@unl.edu

Peter S. Beevor

Natural Resources Institute, Kent, UK

Follow this and additional works at: https://digitalcommons.unl.edu/entomologyfacpub

Part of the Entomology Commons

Youm, Ousmane and Beevor, Peter S., "Field Evaluation of Pheromone-Baited Traps for Coniesta ignefusalis (Lepidoptera: Pyralidae) in Niger" (1995). Faculty Publications: Department of Entomology. 287.

https://digitalcommons.unl.edu/entomologyfacpub/287

This Article is brought to you for free and open access by the Entomology, Department of at DigitalCommons@University of Nebraska - Lincoln. It has been accepted for inclusion in Faculty Publications: Department of Entomology by an authorized administrator of DigitalCommons@University of Nebraska - Lincoln. 


\title{
Field Evaluation of Pheromone-Baited Traps for Coniesta ignefusalis (Lepidoptera: Pyralidae) in Niger
}

\author{
OUSMANE YOUM ${ }^{1}$ AND PETER S. BEEVOR ${ }^{2}$
}

\begin{abstract}
J. Econ. Entomol. 88(1): 65-69 (1995)
ABSTRACT Studies were conducted in Niger to compare pheromone-baited trapping systems for monitoring adults of the millet stem borer, Coniesta ignefusalis (IIampson), a pest of pearl millet, Pennisetum glaucum (L.) R. Brown. A water-oil trap was effective after optimization of various trap parameters. A trap tray of $32-\mathrm{cm}$ diameter was more effective and easier to handle than other sizes tested. Optimum trap shade size was 8-21 cm, positioned $2-5 \mathrm{~cm}$ above the tray. Motor oil, soap, or liquid detergent were more effective than vegetable oil as surfactants. The experimentad trap caught significantly more male moths than four commercial traps. More moths were caught with large, thick polythene vial pheromone dispensers than small, thin vials, but the attractiveness of both declined significantly within $14 \mathrm{~d}$. Trap catches were not greatly affected by the height of the crop or by the height of the trap above ground level when the traps were placed individually at different sites. However, when traps were stacked at different heights at one site, more moths were caught in traps at heights of $0.10-0.50 \mathrm{~m}$ than at 1.30 and $2.0 \mathrm{~m}$ above ground level, regardless of crop height. This system is appropriate for monitoring of pest populations by subsistence farmers and national and international agricultural research stations in the Sahelian region of Africa.
\end{abstract}

KEY WORDS Coniesta ignefusalis, Pennisetum glaucum, pheromone

THE MILIAT STEM BORER, Coniesta ignefusalis (Hampson), is an important stem borer pest of pearl millet, Pennisetum glaucum (L.) R. Brown, in the West African Sahelian and Sudano-Sahelian zones (Harris 1962, N'doye \& Gahukar 1987, Youm 1990). Damage and crop losses caused by C. ignefusalis range from $15 \%$ to total crop failure (Harris 1962, Ajayi 1990). Estimation of damage or infestation by $C$. ignefusalis is based either on field inspections or on destructive sampling by dissection of stems. Although larval behavior has been studied (Harris 1962), monitoring of adult populations has not been reported, and monitoring is currently based on data from light traps located at research stations. Little is known of the movement of adult moths after emergence from pupae at their overwintering sites. Knowledge of adult behavior, particularly with respect to migration, is essential before pest-management strategies can be developed.

Pheromone traps provide a means for sensitive and specific monitoring of adult moth populations even at low densities (Srivastava \& Srivastava 1989). Preliminary research on design and evaluation of pheromone traps baited with the female sex pheromone of $C$. ignefusalis showed that a standard commercially available pheromone trap was relatively ineffective for catching $C$. ignefusalis

\footnotetext{
Intemational Crops Research Institute for the Semi-Arid Tropics, Sahelian Center, B.P. 12404 Niamey, Niger.

a Natural Resources Institute, Central Avenue, Chatham Maritime, Chatham, Kent ME4 4TB England.
}

male moths, whereas a water-oil trap showed promise as an effective trap (Youm et al. 1993). Our objectives were to optimize and compare the water-oil trap with other trap designs for use in population monitoring and assessment both at research stations and at farmers' millet fields.

\section{Materials and Methods}

Water-Oil Traps. Unless otherwise stated, water-oil traps consisted of aluminum trays $(32-\mathrm{cm}$ diameter) filled with water to a depth of $2 \mathrm{~cm}$ and containing $17 \mathrm{ml}$ Total rubia $\mathrm{S}-40$ oil (SIFAL, RCI) as a surfactant. The tray was supported at $0.5 \mathrm{~m}$ above ground level on a horizontal, brownish, nonglossy wooden shelf $(40$ by $40 \mathrm{~cm}$ ) fixed to a wooden stake. A shade consisting of a plastic dish (21$\mathrm{cm}$ diameter) was suspended $5 \mathrm{~cm}$ above the tray from a horizontal support also fixed to the wooden stake, and the shade was secured to the tray with wire. Experiments were designed to examine the effect on catches of tray diameter, shade diameter, shade height, shade shape, type of surfactant (new motor oil, used motor oil, liquid detergent, refined vegetable oil, and soap), and trap height relative to crop height. In the latter experiments, crop height was determined by measuring all plants within a $5-\mathrm{m}$ radius of each trap during the second and third day of each experiment.

Other Trap Designs. The four commercially available traps tested were: sticky board trap (60 $\times 60 \mathrm{~cm}$, Agrisense-BCS, UK), a plastic funnel trap (11-cm diameter, Agrisense-BCS), a sticky 
Table 1. Catches of C. ignefusalis male moths in pheromone-baited water-oil traps with various tray diameters

\begin{tabular}{ccc}
\hline Tray diam, cm & Total catch $^{a}$ & $\begin{array}{c}\text { Mean catch per trap } \\
\text { per night } \pm \text { SEM }\end{array}$ \\
\hline 29 & $158(50)$ & $3.2 \pm 0.5 \mathrm{bc}$ \\
32 & $200(48)$ & $4.2 \pm 0.7 \mathrm{ab}$ \\
34 & $222(47)$ & $4.7 \pm 1.0 \mathrm{ab}$ \\
47 & $259(46)$ & $5.6 \pm 0.9 \mathrm{a}$ \\
\hline
\end{tabular}

Means followed by same letter are not significantly different $(P$ $>0.05$; LSD test [SAS Institute 1987]).

${ }^{a}$ Number of trap nights in parentheses.

delta trap (Sentry, USA), and a sticky $3 \mathrm{M}$ wing trap (Sentry). Funnel traps contained a 1- by 2 -cm strip of $20 \%$ Vapona (PVC impregnated with dichlorvos, Agrisense-BCS) to kill trapped moths.

Pheromone Dispensers. Unless otherwise stated, traps were baited with polythene vials ( 32 by 15 by $2 \mathrm{~mm}$ thick (Agrisense-BCS) impregnated with the optimum pheromone blend of $(Z)$-7-dodecen-1-ol (Z7-12:OH) (500 $\mu \mathrm{g})+(\mathrm{Z})$-5-decen-1ol (Z5-10:OH) $(25 \mu \mathrm{g})+(\mathrm{Z})$-7-dodecenal (Z7-12 CHO) $(16.67 \mu \mathrm{g})$ and an equal amount of BHT antioxidant. The pheromone components were prepared at the Natural Resources Institute (NRI), Chatham, UK, and were $>99.9 \%$ isomerically pure. Dispensers were suspended from the underside of the shade on small wire with an end loop that was extended through the lid and tied to the horizontal wooden support. Results with these dispensers were compared with those from smaller dispensers consisting of polythene vials ( 20 by 8 by $1.5 \mathrm{~mm}$ thick) impregnated with the same pheromone mixture.

Experimental Design. Trap design studies were conducted in village millet farms near the International Crops Research Institute for the SemiArid Tropics (ICRISAT) - Sahelian Center at Sadoré, Niger. Traps were positioned $\approx 25 \mathrm{~m}$ apart in a circular arrangement within a replicate, and replicates were separated by at least $100 \mathrm{~m}$. Moth catches were recorded and removed each day when the traps with their pheromone dispensers were moved clockwise one position within a replicate. There were generally four to five treatments with five to six replicates, and experiments were continued for 4-10 nights until each treatment had

Table 2, Catches of $C$. ignefusalis male moths in water-oil traps with different shade diameters

\begin{tabular}{ccc}
\hline \hline $\begin{array}{c}\text { Trap shade } \\
\text { diam, cm }\end{array}$ & Total catch $^{a}$ & $\begin{array}{c}\text { Mean catch per trap } \\
\text { per night } \pm \text { SEM }\end{array}$ \\
\hline 0 & $683(28)$ & $24.4 \pm 3.4 \mathrm{~b}$ \\
8 & $830(28)$ & $29.6 \pm 3.6 \mathrm{a}$ \\
21 & $1,028(28)$ & $36.7 \pm 5.6 \mathrm{a}$ \\
32 & $724(30)$ & $24.1 \pm 5.2 \mathrm{~b}$ \\
40 & $371(30)$ & $12.4 \pm 2.3 \mathrm{c}$ \\
\hline
\end{tabular}

Means followed by same letter are not significantly different ( $P$ $>0.05$; LSD test [SAS Institute 1987]).

${ }^{a}$ Number of trap nights in parentheses.
Table 3. Catches of $C$. ignefusalis male moths in water-oil traps with various shade heights above tray rim

\begin{tabular}{ccc}
\hline $\begin{array}{c}\text { Trap shade } \\
\text { ht, cm }\end{array}$ & Total catch & $\begin{array}{c}\text { Mean catch per trap } \\
\text { per night } \pm \text { SEM }\end{array}$ \\
\hline 2 & $538(22)$ & $24.4 \pm 3.9 \mathrm{a}$ \\
5 & $583(24)$ & $24.3 \pm 4.0 \mathrm{a}$ \\
10 & $195(24)$ & $8.1 \pm 1.2 \mathrm{~b}$ \\
15 & $132(24)$ & $5.5 \pm 0.7 \mathrm{~b}$ \\
\hline
\end{tabular}

Means followed by same letter are not significantly different ( $P$ $>0.05$; LSD test [SAS Institute 1987]).

a Number of trap nights in parentheses.

occupied each position one or two times. The levels of water and surfactant were checked every day for evaporation and replaced if necessary. Dispensers were left in the traps for the duration of the experiment with the shade, which protected them from direct sunlight.

Data for each experiment were transformed using natural logarithm as $y t=\operatorname{Ln}(y+1)$, where $y$ is the number of moths caught per trap for each night, before analysis of variance (ANOVA [SAS Institute 1987]). Differences in mean trap catches were tested for significance using least significant difference (LSD [SAS Institute 1987]).

\section{Results and Discussion}

Effect of Tray Size. Catches with aluminum trays of $29,32,34$, and $47-\mathrm{cm}$ diameter were compared. Shade diameter was $21 \mathrm{~cm}$ for all tray sizes tested. Catches of male $C$. ignefusalis moths were significantly different between tray of different sizes $(F=5.6 ; \mathrm{df}=4,16 ; P<0.01$ ) (Table 1). There were no significant differences in trap catches with tray diameter of 47,34 , and $32 \mathrm{~cm}$, but the trays of $29-\mathrm{cm}$ diameter caught significantly fewer moths than trays of $47-\mathrm{cm}$ diameter. Although most moths were caught in traps with a $47-\mathrm{cm}$ tray, large trays are difficult to handle, have higher evaporation rates, and are more easily disturbed by wind.

Effect of Shade Size. Catches in traps with aluminum disks of $8,21,32$, and $40-\mathrm{cm}$ diameter as shades were compared with those in traps with no shade. Tray diameter was $32 \mathrm{~cm}$ for all shade sizes tested. Trap shade size significantly affected catch-

Table 4. Catches of $C$. ignefusalis male moths in water-oil traps with different shade shapes

\begin{tabular}{lcc}
\hline \multicolumn{1}{c}{ Trap shade } & Total catcha & $\begin{array}{c}\text { Mean catch } \\
\text { per trap per } \\
\text { night } \pm \text { SEM }\end{array}$ \\
\hline Dish shape (plastic) & $200(47)$ & $4.3 \pm 0.4 \mathrm{a}$ \\
Disk shape (aluminum) & $110(48)$ & $2.3 \pm 0.3 \mathrm{~b}$ \\
Dish shape, vertical & $182(48)$ & $3.8 \pm 0.4 \mathrm{a}$ \\
$\quad$ edge (aluminum) & $173(47)$ & $3.7 \pm 0.4 \mathrm{a}$ \\
\hline
\end{tabular}

Means followed by same letter are not significantly different $(P$ $>0.05$; LSD test [SAS Institute 1987]).

${ }^{a}$ Number of trap nights in parentheses. 
Table 5. Catches of $C$. ignefusalis male moths in water-oil trapes with different surfactants

\begin{tabular}{lrc}
\hline \multicolumn{1}{c}{ Surfuctant } & Total catch & \\
\hline Motor oil (new) & $\begin{array}{c}\text { Mean catch } \\
\text { per trap per } \\
\text { night } \pm \text { SEM }\end{array}$ \\
Motor oil (used) & $1,134(29)$ & $39.1 \pm 4.4 \mathrm{a}$ \\
lduid deterge'nt & $1,276(29)$ & $44.0 \pm 5.1 \mathrm{a}$ \\
Soap & $1,161(30)$ & $38.7 \pm 3.6 \mathrm{a}$ \\
Vegetable oil & $1,278(30)$ & $42.6 \pm 4.7 \mathrm{a}$ \\
\hline
\end{tabular}

Meaus followed by same letter are not significantly different $(P$ $>0.05 ;$ ISI) test [SAS Institute 1987])

a Number of trap nights in parentheses.

es of male $C$. ignefusalis moths. Traps with shade diameters of 8 and $21 \mathrm{~cm}$ caught significantly more male moths than traps with no shade or with shade sizes of 32 and $40-\mathrm{cm}$ diameter $(F=24.4 ; \mathrm{df}=4$, $20 ; P<0.001$ ) (Table 2). It is likely that with smaller shades, moths could more easily approach the pheromone dispenser without touching the oil-water surface and becoming caught, whereas shades larger than the tray discouraged moths from reaching the tray.

Effect of Trap Shade Height. Catches of male moths in standard traps with the shade at heights of $2,5,10$, and $15 \mathrm{~cm}$ above the tray rim were compared. Significantly more moths were caught when the shade height was 2 or $5 \mathrm{~cm}$ than when the height was 10 or $15 \mathrm{~cm}(F=26.3$; $\mathrm{df}=3,15$; $P<0.001$ ) (Table 3). There was no significant difference in male moth catches among traps with shade heights of 2 and $5 \mathrm{~cm}$ or among traps with shade heights of 10 and $15 \mathrm{~cm}$. The larger gaps between shade: and tray may have allowed moths to escape without touching the oil-water surface.

Effect of Trap Shade Shape. The shades tested were a dish, a flat disk, a disk with a vertical edge, all in aluminum, and a plastic dish. Trap shade shape significantly affected trap catch $(F=11.20$; df $=3,15 ; P<0.001$ ). Traps with disk-shaped shades caught significantly less male moths than traps with dish-shaped shades or dish-shaped shades with a vertical edge (Table 4). Plastic and aluminum dishes were equally effective in these tests, but plastic can become brittle and deteriorate after prolonged exposure to sunlight; thus aluminum may be more durable for outdoor use.

Table 6. Catches of male $C$. ignefusalis moths in different trap designs

\begin{tabular}{lcc}
\hline \hline Trap design & Total catch $^{a}$ & $\begin{array}{c}\text { Mean catch per trap } \\
\text { per night } \pm \text { SEM }\end{array}$ \\
\hline Watter-oil & $842(28)$ & $30.1 \pm 2.3 \mathrm{a}$ \\
Sticky board & $288(30)$ & $9.6 \pm 1.8 \mathrm{~b}$ \\
Plastic funnel & $32(30)$ & $1.1 \pm 0.2 \mathrm{~d}$ \\
Sticky deltit & $27(28)$ & $1.0 \pm 0.3 \mathrm{~d}$ \\
Sticky 3M & $70(30)$ & $2.3 \pm 0.4 \mathrm{c}$ \\
\hline
\end{tabular}

Means followed by same letter are not significantly different $(P$ $>0.05$; LSD test [SAS Institute 1987]).

${ }^{a}$ Number of trap nights in parentheses.
Table 7. Longevity of large and small polythene vial pheromone dispensers in water-oil traps

\begin{tabular}{rrrrrr}
\hline \hline $\begin{array}{c}\text { Expo- } \\
\text { sure } \\
\text { time, } \\
\mathrm{d}\end{array}$ & \multicolumn{2}{c}{ Large vials } & & \multicolumn{2}{c}{ Small vials } \\
\cline { 3 - 5 } \cline { 5 - 6 } catch $^{a}$ & $\begin{array}{c}\text { Mean catch } \\
\text { per trap per } \\
\text { night } \pm \text { SEM }\end{array}$ & & $\begin{array}{c}\text { Total } \\
\text { catch }^{a}\end{array}$ & $\begin{array}{c}\text { Mean catch } \\
\text { per trap per } \\
\text { night } \pm \text { SEM }\end{array}$ \\
\hline 0 & $260(24)$ & $10.8 \pm 1.8 \mathrm{a}$ & & $359(24)$ & $15.0 \pm 1.7 \mathrm{a}$ \\
14 & $148(23)$ & $6.4 \pm 1.4 \mathrm{~b}$ & & $83(24)$ & $3.5 \pm 0.7 \mathrm{~b}$ \\
28 & $58(22)$ & $2.6 \pm 1.1 \mathrm{c}$ & & $39(24)$ & $1.6 \pm 0.4 \mathrm{c}$ \\
42 & $35(21)$ & $1.7 \pm 0.6 \mathrm{c}$ & & $31(24)$ & $1.3 \pm 0.4 \mathrm{c}$ \\
\hline
\end{tabular}

Means followed by same letter are not significantly different $(P$ $>0.05$; LSD test [SAS Institute 1987]).

a Number of trap nights in parentheses.

Effect of Surfactant Type. New motor oil, used motor oil, liquid detergent, refined vegetable oil, and soap were compared as surfactants. The soap treatment involved agitating a bar of soap in the water for $1 \mathrm{~min}$ until foamy. The type of surfactant significantly affected trap catches $(F=15.3 ; \mathrm{df}=$ 4,$20 ; P<0.001$ ) (Table 5). The use of motor oil (used or new), soap, or liquid detergent resulted in significantly higher catches of male $C$. ignefusalis moths than the use of vegetable oil. Motor oil may reduce the evaporation rate of the water, but in villages, oil may not be as readily available as a bar of soap.

Comparison of Trap Designs. There was a significant difference in captures of male $C$. ignefusalis moths among trap types $(F=115.1, \mathrm{df}=4$, $20 ; P<0.001$ ) (Table 6). The water-oil trap caught significantly more male moths than any of the other traps, followed by the sticky board trap and the wing trap. There was no significant difference in male moth catches between the funnel and delta traps, which caught the fewest numbers of male moths.

Longevity of Pheromone Dispensers. Samples of the standard and the smaller dispensers were exposed in traps for 14,28 , and $42 \mathrm{~d}$ before comparing with results with fresh dispensers. Exposure time of large or small pheromone dispensers before testing significantly affected trap catches $(F=$ 34.3 [large], $F=35.7$ [small]; $\mathrm{df}=3,15 ; P<$ $0.001)$ (Table 7). Traps baited with dispensers without previous exposure (control) caught significantly more male moths than traps with exposed dis-

Table 8. Comparison of attractiveness of large and small polythene vial pheromone dispensers in water-oil traps

\begin{tabular}{lccc}
\hline Dispenser & $\begin{array}{c}\text { Exposure } \\
\text { time, d }\end{array}$ & Total catch $^{a}$ & $\begin{array}{c}\text { Mean catch per trap } \\
\text { per night } \pm \text { SEM }\end{array}$ \\
\hline Large & 0 & $452(24)$ & $18.8 \pm 2.9 \mathrm{a}$ \\
Large & 33 & $62(24)$ & $2.6 \pm 0.5 \mathrm{c}$ \\
Small & 0 & $276(24)$ & $11.5 \pm 1.9 \mathrm{~b}$ \\
Small & 33 & $22(24)$ & $0.9 \pm 0.2 \mathrm{~d}$ \\
\hline
\end{tabular}

Means followed by same letter are not significantly different $(P$ $>0.05$; LSD test [SAS Institute 1987]).

${ }^{a}$ Number of trap nights in parentheses. 
Table 9. Effect of trap height in relation to crop height on catches of male $C$. ignefiusalis moths in water-oil traps stacked vertically

\begin{tabular}{|c|c|c|c|c|c|c|c|c|}
\hline \multirow{3}{*}{$\begin{array}{l}\text { Trap } \\
\text { ht, m }\end{array}$} & \multicolumn{8}{|c|}{ Crop ht, m } \\
\hline & \multicolumn{2}{|r|}{0.44} & \multicolumn{2}{|r|}{0.79} & \multicolumn{2}{|r|}{1.31} & \multicolumn{2}{|r|}{1.63} \\
\hline & $\begin{array}{c}\text { Total } \\
\text { catch }^{a}\end{array}$ & $\begin{array}{l}\text { Mean catch } \\
\text { per trap per } \\
\text { night } \pm \text { SEM }\end{array}$ & $\begin{array}{c}\text { Total } \\
\text { catch }^{a}\end{array}$ & $\begin{array}{l}\text { Mean catch } \\
\text { per trap per } \\
\text { night } \pm \text { SEM }\end{array}$ & $\begin{array}{c}\text { Total } \\
\text { catcho }^{\circ}\end{array}$ & $\begin{array}{l}\text { Mean catch } \\
\text { per trap per } \\
\text { night } \pm \text { SEM }\end{array}$ & $\begin{array}{c}\text { Total } \\
\text { catch } a\end{array}$ & $\begin{array}{c}\text { Mean catch } \\
\text { per trap per } \\
\text { night } \pm \text { SEM }\end{array}$ \\
\hline 0.10 & 400 & $16.7 \pm 3.8 \mathrm{a}$ & 236 & $9.8 \pm 2.1 \mathrm{a}$ & 89 & $3.7 \pm 0.7 a$ & 297 & $12.4 \pm 2.1 \mathrm{a}$ \\
\hline 0.50 & 129 & $5.4 \pm 1.7 b$ & 137 & $5.7 \pm 1.0 b$ & 34 & $1.4 \pm 0.3 b$ & 190 & $7.9 \pm 1.0 \mathrm{a}$ \\
\hline 1.30 & 4 & $0.2 \pm 0.1 \mathrm{c}$ & 18 & $0.7 \pm 0.3 \mathrm{c}$ & 5 & $0.2 \pm 0.1 \mathrm{c}$ & 39 & $1.6 \pm 0.3 b$ \\
\hline 2.00 & 0 & 0 & $1^{b}$ & $0.04 \pm 0.04 \mathrm{~d}$ & 0 & 0 & 5 & $0.2 \pm 0.1 c$ \\
\hline
\end{tabular}

Means followed by same letter are not significantly different $(p>0.05$; LSD test [SAS Institute 1987]).

a Number of trap nights was 24 for each experiment except as noted.

${ }^{b}$ Number of trap nights was 23 .

pensers. Traps with dispensers exposed for $14 \mathrm{~d}$ before testing caught significantly more male moths than dispensers exposed for either 28 or 42 d. There was no significant difference in the numbers of male C. ignefusalis moths caught between traps baited with dispensers exposed for 28 and $42 \mathrm{~d}$.

Comparison of Pheromone Dispensers. In a second experiment, the standard and the smaller dispensers were compared as fresh lures and as lures that previously had been exposed in traps for $33 \mathrm{~d}$. Male moth catches were significantly different among dispenser types and exposure times $(F$ $=43.3$; $\mathrm{df}=3,15 ; P<0.001$ ) (Table 8). Large dispensers without previous exposure were significantly more attractive than large dispensers exposed for $33 \mathrm{~d}$. Similarly, new, unexposed small dispensers were more attractive than small dispensers exposed for $33 \mathrm{~d}$. Also, large dispensers were more attractive than small dispensers when new and after $33 \mathrm{~d}$ exposure. Thus, the larger dispensers are more effective than the small dispensers, and, although they retain some attractiveness for at least $42 \mathrm{~d}$, they should be renewed at least every $2 \mathrm{wk}$.

Effects of Trap and Crop Heights. In a first experiment, traps were stacked vertically on one stake at heights of $0.1,0.5,1.3$, and $2.0 \mathrm{~m}$ above ground level. This arrangement was replicated at six sites at least $100 \mathrm{~m}$ apart. For all crop heights, significantly more male moths were caught at trap heights of 0.10 and $0.50 \mathrm{~m}$ above ground level than in traps at 1.30 and $2.0 \mathrm{~m}(F=66.6$; $\mathrm{df}=2,10$; $P<0.001$ for crop height of $0.44 \mathrm{~m} ; F=39.2 ; \mathrm{df}$ $=3,15 ; P<0.001$ for crop height of $0.79 \mathrm{~m} ; F=$ $17.3 ; \mathrm{df}=2,10 ; P<0.001$ for crop height of 1.31 $\mathrm{m}$; and $F=35.5$; $\mathrm{df}=3,15 ; P<0.001$ for crop height of $1.63 \mathrm{~m}$ ) (Table 9).

In a second experiment, traps were placed separately at the four heights given above in the standard experimental design. For all crop heights $(0.99-2.93 \mathrm{~m})$, there were no significant differences in catches of male moths among trap heights $(P>0.05)$ at three stages of growth with different moth densities (Table 10).

These results indicate that the positioning of traps for monitoring is not critical, regardless of the crop height or moth density. However, the different results with the two different arrangements of traps have not been reported before, although numerous studies using the second arrangement of traps and at different heights at different sites have been described for other species. For example, with the Mexican rice borer, Eoreuma loftini (Dyar), Shaver et al. (1991) found no significant difference in male catches in Unitraps placed $5 \mathrm{~m}$ within a field at heights of $0.46,1.02$, and $1.58 \mathrm{~m}$, although traps at $2.14 \mathrm{~m}$ caught significantly fewer moths. For Pherocon $1 \mathrm{C}$ traps, they noticed no significant differences in catches at the different heights. However, when traps were placed at the edge of a field, more male moths were caught at

Table 10. Effect of trap height in relation to crop height on catches of male $C$. ignefusalis moths in water-oil traps, single traps at each site

\begin{tabular}{|c|c|c|c|c|c|c|}
\hline \multirow{3}{*}{$\begin{array}{l}\text { Trap } \\
\text { ht, m }\end{array}$} & \multicolumn{6}{|c|}{ Crop ht, m } \\
\hline & \multicolumn{2}{|r|}{1.0} & \multicolumn{2}{|r|}{1.5} & \multicolumn{2}{|r|}{2.9} \\
\hline & Total catcha & $\begin{array}{l}\text { Mean catch per trap } \\
\text { per night } \pm \text { SEM }\end{array}$ & Total catch ${ }^{a}$ & $\begin{array}{l}\text { Mean catch per trap } \\
\text { per night } \pm S E M\end{array}$ & Total catch ${ }^{a}$ & $\begin{array}{l}\text { Mean catch per trap } \\
\text { per night } \pm \text { SEM }\end{array}$ \\
\hline 0.10 & 66 & $2.7 \pm 0.5 a$ & 245 & $10.2 \pm 1.7 \mathrm{a}$ & 55 & $2.3 \pm 0.4 a$ \\
\hline 0.50 & 58 & $2.4 \pm 0.4 \mathrm{a}$ & 314 & $13.1 \pm 1.9 a$ & 71 & $3.0 \pm 0.5 \mathrm{a}$ \\
\hline 1.30 & 50 & $2.1 \pm 0.4 \mathrm{a}$ & 378 & $15.7 \pm 3.3 \mathrm{a}$ & 68 & $2.8 \pm 0.4 \mathrm{a}$ \\
\hline 2.00 & 30 & $1.2 \pm 0.4 \mathrm{a}$ & 344 & $14.3 \pm 2.7 \mathrm{a}$ & 53 & $2.2 \pm 0.4 \mathrm{a}$ \\
\hline
\end{tabular}

Means followed by same letter are not significantly different ( $P>0.05$; LSD test [SAS Institute 1987]).

a Number of trap nights was 24 for each experiment. 
heights of 0.46 and $1.02 \mathrm{~m}$ than at 1.58 and 2.14 $\mathrm{m}$. They also indicated in the discussion that moths were flying at $0.50-0.70 \mathrm{~m}$ above ground level during sexual activity, in agreement with the results that traps at that height caught most moths. Our studies suggest that such conclusions may possibly be misleading. $C$. ignefusalis male moths may fly to a trap between 0.1 and $2.0 \mathrm{~m}$ above ground level in a no-choice situation, but moths favor traps at $0.1-0.5 \mathrm{~m}$ when given a choice. It is possible that C. ignefusalis, a low flyer, conducts mate searching and sexual activity within $0.10 \mathrm{~m}$ and $0.50 \mathrm{~m}$ of ground level. However, it is also possible that interaction of the pheromone plumes from traps stacked at different heights at one site affect moth behavior.

Our study was done to develop and evaluate the parameters of an efficient pheromone-baited trap design for use with the $C$. ignefusalis synthetic pheromone for monitoring of pest populations by subsistence farmers and national and international agricultural research stations in the Sahelian region of Africa. Criteria, thus, included availability and cheapness, while avoiding use of imported or specially-made items such as trap sticker or corrugated plastic sheeting. Our data has identified a wateroil trap consisting of materials that are readily available at a cost of less than U.S. $\$ 5$. Because of the high average $24-\mathrm{h}$ temperature of at least $30^{\circ} \mathrm{C}$ and the high volatility of the $C$. ignefusalis pheromone components, pheromone dispensers should be renewed at least every $14 \mathrm{~d}$.

\section{Acknowledgments}

We thank Amadou Diop (research assistant), technicians, and field workers in the Entomology Unit at ICRISAT Sahelian Center for assistance during field studies, and farmers in the villages of Deybon, Bellare, and Sadore for their collaboration during field trials. This article was approved by ICRISAT as Journal Article No. 1527 and by NRI.

\section{References Cited}

Ajayi, O. 1990. Possibilities for the integrated control of the millet stem borer, Acigona ignefusalis Hampson (Lepidoptera: Pyralidae), in Nigeria. Insect Sci. Appl. 11: $109-117$.

Harris, K. M. 1962. Lepidopterous stemborers of cereals in Nigeria. Bull. Entomol. Res. 53: 139-171.

N'doye, M. \& R. T. Gahukar. 1987. Insect pests of pearl millet in West Africa and their control, pp. 195 205. In ICRISAT (International Crops Research Institute for the Semi-Arid Tropics): Proceedings, International Pearl Millet Workshop, 7-11 April 1986. ICRISAT Center, Patancheru, A. P. 502 324, India.

SAS Institute. 1987. SAS/STAT guide for personal computers, version 6 ed. SAS Institute, Cary, NC.

Shaver, T. N., H. E. Brown, J. W. Burd, T. C. Holler \& D. E. Hendricks. 1991. Field evaluation of pheromone-baited traps for monitoring Mexican rice borer (Lepidoptera: Pyralidae). J. Econ. Entomol. 84: 12161219.

Srivastava, C. P. \& R. P. Srivastava. 1989. Comparison of Heliothis armigera (Hübner) male moth catches in light and pheromone traps at Udaipur, Rajasthan, India. Insect Sci. Appl. 10: 565-568.

Youm, 0. 1990. Evaluation of natural enemies associated with the millet stalk borer, Haimbachia ignefusalis (Hampson) (Lepidoptera: Pyralidae) in Niger. Ph.D dissertation. Texas A\&M University, College Station.

Youm, O., P. S. Beevor \& D. R. Hall. 1993. Trap design studies with the pheromone of $C$. ignefusalis (Hampson) (Lepidoptera: Pyralidae) in sub-Saharan Africa. International Organization for Biological Control of Noctious Animals and Plants, Western Palaeartic Regional Section (IOBC/WPRS) Bull. 16(10): 586.3.

Received for publication 23 November 1993; accepted 20 July 1994. 